\title{
Partners for life: a brittle star and its octocoral host
}

\author{
Celeste V. Mosher ${ }^{1}$, Les Watling ${ }^{1,2, *}$ \\ ${ }^{1}$ Darling Marine Center, University of Maine, 192 Clarks Cove Road, Walpole, Maine 04573, USA \\ ${ }^{2}$ Present address: Department of Zoology, 152 Edmondson Hall, University of Hawaii at Manoa, Honolulu, Hawaii 96822, USA
}

\begin{abstract}
Throughout the New England and Corner Rise seamounts of the western North Atlantic Ocean, several ophiuroid species are conspicuously epizoic on octocorals. One species, Ophiocreas oedipus, was found only on the chrysogorgiid octocoral Metallogorgia melanotrichos. Colonies of M. melanotrichos were collected from 11 seamounts during expeditions in 2003, 2004, and 2005 at depths between 1300 and $2200 \mathrm{~m}$. O. oedipus is obligately associated with $M$. melanotrichos, leading a solitary existence on all octocorals observed. Evidence suggests that a young brittle star settles directly on a young octocoral and the 2 species then grow, mature, and senesce together. The brittle star benefits directly by being above the bottom for suspension feeding and is passively protected by the octocoral, but the latter, as far as we have been able to determine, seems neither to benefit nor be disadvantaged by the relationship.
\end{abstract}

KEY WORDS: Octocoral · Brittle star $\cdot$ Ophiocreas $\cdot$ Metallogorgia $\cdot$ Commensal relationship New England seamounts · Corner Rise seamounts

\section{INTRODUCTION}

Symbioses between invertebrates and their hosts are not well studied in the deep sea, presumably because of the difficulty of observation and lack of opportunity to make repeated observations. Even so, a number of species have been described from deep-sea corals and their relationships inferred based on observations made at the time of collection (see Buhl-Mortensen \& Mortensen 2004, their Table 1). Some of the relationships are obligate - the symbiont occurs only on one or a few host species - while others appear to be facultative. For example, the polychaete worm Gorgoniapolynoe caeciliae (Fauvel, 1913) constructs tubes in the tissue of some species of Corallium Lamarck, but also inhabits colonies of the primnoid Candidella imbricata (Johnson, 1862), where it induces the host to make an 'arbor vita'-like tunnel of modified sclerites (Eckelbarger et al. 2005). On the other hand, species of the ophiuroid genus Ophiacantha Müller and Troeschel, 1842, can be found on various deep-sea coral species, both gorgonians and scleractinians. Of the known symbiotic associations with deep-sea corals, BuhlMortensen \& Mortensen (2004) estimate only 32\% are obligately associated with their hosts. Of the obligate associations, $53 \%$ are parasitic and $47 \%$ apparently live commensally with their hosts.

The brittle star order Euryalida (=Euryalinida) includes the basket stars (Family Gorgonocephalidae) and snake stars (Families Asteronychidae, Asteroschematidae, and Euryalidae). Basket stars are moderately common in shallow cold waters and so have received some ecological study. The other 3 families, however, are some of the least studied ophiuroids, likely because most known species occur in the deep sea. While the feeding characteristics and basic biology of asteroschematid and asteronychid species have been studied (Hendler \& Miller 1984, Emson \& Woodley 1987, Fujita \& Ohta 1988, Grange 1991, Stewart \& Mladenov 1997), the dynamics of their host associations are poorly known. Host fidelity of asteroschematids ranges from being found on a single host species (Emson \& Woodley 1987, Grange 1991) to occurrence on many different coral species (Fujita 2001, L. Watling pers. obs.).

Our knowledge of asteroschematid biology comes primarily from 3 studies: 2 conducted in the shallow fjords of New Zealand (Grange 1991, Stewart 1998), 
and the other from a series of moderately shallow (to $244 \mathrm{~m}$ ) submersible dives made off Discovery Bay, Jamaica (Emson \& Woodley 1987). In New Zealand, the ophiuroid Astrobrachion constrictum is found only on the antipatharian Antipathella fiordensis. Individual brittle stars removed from their host colony were observed to move rapidly across the substrate until another host colony was encountered (Stewart 1998). Each host colony may harbor several ophiuroids (see frontispiece in McKnight 2000). The brittle star feeds on mucus from the coral colony as well as small planktonic organisms captured by the tube feet and arm spines. Only 5 juveniles were found among the 281 brittle stars sampled, and these almost always inhabited the lower branches of the coral colonies. In Jamaica, the brittle star Asteroschema tenue occurs only on the gorgonian Ellisella barbadensis. Each gorgonian bears a single asteroschematid. No young brittle stars were seen on the 132 host gorgonians examined.

The asteroschematid ophiuroid Ophiocreas oedipus Lyman, 1879 was described from 2 dredge hauls taken by the Challenger expedition off Ascension Island in the Atlantic, and northern Indonesia in the western Pacific (Lyman 1882). Until our work on the New England and Corner Rise seamounts in the northwest Atlantic, this species was known only from the southwest Pacific north of New Zealand and the south Atlantic (McKnight 2000), and possibly off southern Japan (Clark 1911). However, no host information for this brittle star has ever been given, an unfortunate fact for most euryalid brittle stars. In our studies of the New England and Corner Rise seamounts in the north- west Atlantic, we found $O$. oedipus always to be associated with the gorgonian octocoral Metallogorgia melanotrichos. In the present study we present what we know about this association and the biology of the 2 species. We hypothesize that the brittle star settles onto young $M$. melanotrichos and the 2 species then live together their entire lives.

\section{MATERIALS AND METHODS}

The New England seamounts form a chain extending southeasterly off the northeastern United States, from Bear seamount (located at approximately $39^{\circ} 50^{\prime} \mathrm{N}$, $\left.67^{\circ} 20^{\prime} \mathrm{W}\right)$ to Nashville seamount $\left(34^{\circ} 30^{\prime} \mathrm{N}, 56^{\circ} 50^{\prime} \mathrm{W}\right)$. The Corner Rise complex clusters around $34^{\circ} \mathrm{N}, 49^{\circ} \mathrm{W}$ (Fig. 1). The summits of these undersea mountains range from $\sim 1.4$ to $3.5 \mathrm{~km}$ water depth. Temperatures at these depths are between 3 and $4^{\circ} \mathrm{C}$.

As part of the NOAA Ocean Exploration program, research cruises to the Corner Rise and New England seamounts were conducted in July 2003, May 2004, and August and October 2005. Specimens were collected using the deep submergence vehicle (DSV) 'Alvin' and support ship RV 'Atlantis' in 2003 and during the October cruise of 2005, and the remotely operated vehicle (ROV) 'Hercules', deployed from the NOAA ship 'Ronald H. Brown', in 2004 and August 2005. Sixty-six Metallogorgia melanotrichos colonies were collected at depths between 1300 and $2200 \mathrm{~m}$ from 13 seamounts in the New England and Corner Rise chains (Table 1). In addition, observational data were collected from $\sim 500 \mathrm{~h}$ of video and $\sim 30000$ high-

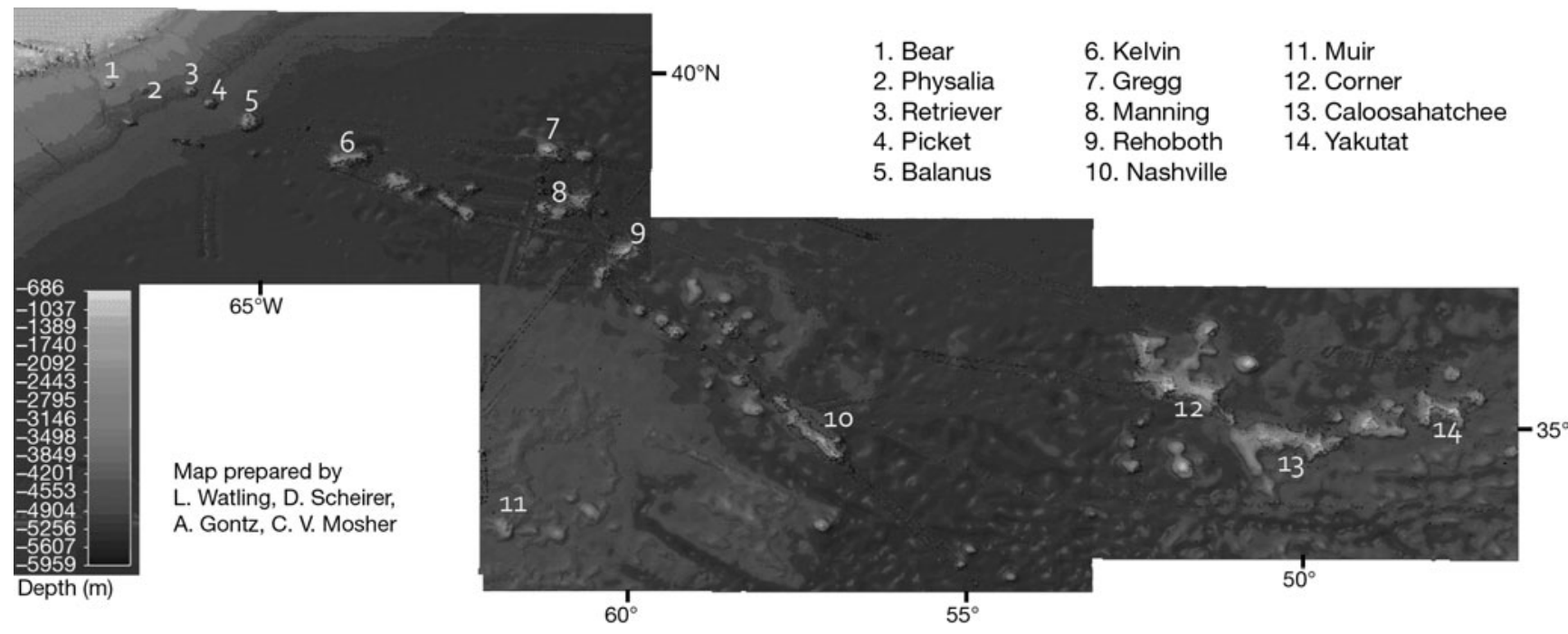

Fig. 1. Bathymetric map of the New England and Corner Rise seamounts, NW Atlantic. Numbered seamounts are those where Metallogorgia melanotrichos and Ophiocreas oedipus have been collected 
Table 1. Metallogorgia melanotrichos and Ophiocreas oedipus. Sampling information and morphological data. NES: New England seamounts; CRS: Corner Rise seamounts. Growth stages - 1: juvenile; 2: intermediate; 3: adult. Dates given as mm/dd/yy

\begin{tabular}{|c|c|c|c|c|c|c|}
\hline $\begin{array}{l}\text { Seamount and } \\
\text { specimen ID }\end{array}$ & Collection date & Latitude $\left({ }^{\circ} \mathrm{N}\right)$ & Longitude $\left({ }^{\circ} \mathrm{W}\right)$ & Depth (m) & $\begin{array}{l}\text { M. melanotrichos } \\
\text { growth stage }\end{array}$ & $\begin{array}{l}\text { O. oedipus disk } \\
\text { diameter (mm) }\end{array}$ \\
\hline \multicolumn{7}{|l|}{ Balanus, NES } \\
\hline BAL101 & $5 / 21 / 04$ & $39^{\circ} 21.30$ & $65^{\circ} 21.52$ & 1912 & 3 & 12.26 \\
\hline BAL107-1 & $5 / 22 / 04$ & $39^{\circ} 21.51$ & $65^{\circ} 21.82$ & 1767 & 3 & 12.64 \\
\hline BAL107-2 & $5 / 22 / 04$ & $39^{\circ} 21.51$ & $65^{\circ} 21.82$ & 1767 & 3 & 11.57 \\
\hline BAL107-3 & $5 / 22 / 04$ & $39^{\circ} 21.51$ & $65^{\circ} 21.81$ & 1767 & 3 & 11.90 \\
\hline BAL110-2 & $5 / 22 / 04$ & $39^{\circ} 22.30$ & $65^{\circ} 22.31$ & 1562 & 1 & 7.25 \\
\hline BAL208-2 & 9/2/05 & $39^{\circ} 24.88$ & $65^{\circ} 24.66$ & 1802 & 2 & 10.13 \\
\hline BAL210-1 & $9 / 2 / 05$ & $39^{\circ} 24.88$ & $65^{\circ} 24.56$ & 1717 & 3 & 12.15 \\
\hline \multicolumn{7}{|l|}{ Bear, NES } \\
\hline BEA401-2 & $5 / 11 / 04$ & $39^{\circ} 57.10$ & $67^{\circ} 24.60$ & 1559 & 1 & 6.29 \\
\hline BEA506-1 & $5 / 12 / 04$ & $39^{\circ} 53.02$ & $67^{\circ} 28.32$ & 1491 & 2 & 10.21 \\
\hline \multicolumn{7}{|l|}{ Goode, CRS } \\
\hline GOO103-1 & $8 / 20 / 05$ & $35^{\circ} 23.61$ & $51^{\circ} 15.93$ & 2135 & 2 & 8.87 \\
\hline GOO106-1 & $8 / 21 / 05$ & $35^{\circ} 23.59$ & $51^{\circ} 15.99$ & 2082 & 3 & 11.85 \\
\hline GOO107-1 & $8 / 21 / 05$ & $35^{\circ} 23.58$ & $51^{\circ} 16.00$ & 2076 & 2 & 7.95 \\
\hline GOO109-1 & $8 / 21 / 05$ & $35^{\circ} 23.57$ & $51^{\circ} 16.05$ & 2051 & 3 & 12.17 \\
\hline \multicolumn{7}{|l|}{ Kelvin, NES } \\
\hline KEL103-1 & $7 / 15 / 03$ & $38^{\circ} 47.33$ & $64^{\circ} 07.91$ & 2029 & 3 & 12.05 \\
\hline KEL107-1 & $7 / 15 / 03$ & $38^{\circ} 47.31$ & $64^{\circ} 07.83$ & 1949 & 1 & 6.61 \\
\hline KEL201-2 & $7 / 16 / 03$ & $38^{\circ} 51.60$ & $63^{\circ} 54.85$ & 2173 & 3 & 10.19 \\
\hline KEL203-3 & $7 / 16 / 03$ & $38^{\circ} 51.51$ & $63^{\circ} 54.85$ & 2047 & 3 & 13.80 \\
\hline KEL301-2 & $5 / 18 / 04$ & $38^{\circ} 49.20$ & $63^{\circ} 57.54$ & 1773 & 1 & 6.50 \\
\hline KEL301-3 & $5 / 18 / 04$ & $38^{\circ} 49.20$ & $63^{\circ} 57.54$ & 1773 & 3 & 12.41 \\
\hline KEL301-4 & $5 / 18 / 04$ & $38^{\circ} 49.20$ & $63^{\circ} 57.54$ & 1773 & 3 & 12.36 \\
\hline KEL607-1 & $8 / 31 / 05$ & $38^{\circ} 45.88$ & $64^{\circ} 05.41$ & 2171 & 3 & 13.74 \\
\hline KEL610-1 & $9 / 1 / 05$ & $38^{\circ} 45.92$ & $64^{\circ} 05.43$ & 2144 & 3 & 9.97 \\
\hline \multicolumn{7}{|l|}{ Kukenthal, CRS } \\
\hline KUK209-1 & $8 / 22 / 05$ & $35^{\circ} 33.40$ & $51^{\circ} 48.89$ & 1829 & 3 & 12.66 \\
\hline \multicolumn{7}{|l|}{ Yukatat, CRS } \\
\hline LYM210-1 & $8 / 14 / 05$ & $35^{\circ} 11.63$ & $47^{\circ} 40.60$ & 2143 & 3 & 12.03 \\
\hline \multicolumn{7}{|l|}{ Manning, NES } \\
\hline MAN706-2 & $5 / 15 / 04$ & $38^{\circ} 08.93$ & $61^{\circ} 06.13$ & 1847 & 2 & 8.02 \\
\hline MAN710-1 & $5 / 15 / 04$ & $38^{\circ} 08.78$ & $61^{\circ} 06.92$ & 1668 & 3 & 10.69 \\
\hline MAN703-1 & $5 / 15 / 04$ & $38^{\circ} 08.93$ & $61^{\circ} 06.14$ & 1867 & 3 & 13.41 \\
\hline MAN706-1 & $5 / 15 / 04$ & $38^{\circ} 08.93$ & $61^{\circ} 06.13$ & 1847 & 3 & 12.24 \\
\hline MAN708-1 & $5 / 15 / 04$ & $38^{\circ} 08.09$ & $61^{\circ} 06.97$ & 1718 & 3 & 12.06 \\
\hline MAN708-2 & $5 / 15 / 04$ & $38^{\circ} 08.09$ & $61^{\circ} 06.97$ & 1718 & 3 & 14.86 \\
\hline MAN801-1 & $5 / 16 / 04$ & $38^{\circ} 08.84$ & $61^{\circ} 05.87$ & 1692 & 3 & 12.90 \\
\hline MAN803-2 & $5 / 16 / 04$ & $38^{\circ} 08.83$ & $61^{\circ} 05.86$ & 1674 & 3 & 12.63 \\
\hline \multicolumn{7}{|c|}{ Caloosahatchee, CRS } \\
\hline MIL103-2 & 8/17/05 & $34^{\circ} 48.92$ & $50^{\circ} 30.35$ & 1601 & 3 & 10.19 \\
\hline MIL105-1 & $8 / 17 / 05$ & $34^{\circ} 48.91$ & $50^{\circ} 30.36$ & 1592 & 3 & 11.81 \\
\hline \multicolumn{7}{|l|}{ Nashville, NES } \\
\hline NAS104-1 & $8 / 25 / 05$ & $34^{\circ} 34.92$ & $56^{\circ} 50.59$ & 2233 & 3 & 12.85 \\
\hline NAS105-1 & $8 / 25 / 05$ & $34^{\circ} 34.88$ & $56^{\circ} 50.59$ & 2221 & 3 & 12.31 \\
\hline NAS110-3 & $8 / 25 / 05$ & $34^{\circ} 34.77$ & $56^{\circ} 50.51$ & 2136 & 3 & 11.46 \\
\hline NAS203-1 & $8 / 26 / 05$ & $34^{\circ} 28.81$ & $56^{\circ} 44.15$ & 2103 & 3 & 11.37 \\
\hline NAS203-2 & $8 / 26 / 05$ & $34^{\circ} 28.81$ & $56^{\circ} 44.15$ & 2103 & 3 & 12.24 \\
\hline \multicolumn{7}{|l|}{ Picket, NES } \\
\hline PIC101-3 & $10 / 28 / 05$ & $39^{\circ} 39.12$ & $65^{\circ} 56.50$ & 2084 & 3 & 13.61 \\
\hline \multicolumn{7}{|l|}{ Rehoboth, NES } \\
\hline REH203-1 & 8/29/05 & $37^{\circ} 33.67$ & $59^{\circ} 48.43$ & 1678 & 2 & 9.16 \\
\hline REH105-1 & $8 / 29 / 05$ & $37^{\circ} 27.63$ & $59^{\circ} 57.08$ & 1907 & 3 & 11.34 \\
\hline REH112-3 & $8 / 29 / 05$ & $37^{\circ} 27.60$ & $59^{\circ} 56.99$ & 1820 & 3 & 11.95 \\
\hline REH212-1 & $8 / 30 / 05$ & $37^{\circ} 33.48$ & $59^{\circ} 48.18$ & 1438 & 3 & 11.71 \\
\hline REH215-1 & $8 / 30 / 05$ & $37^{\circ} 33.37$ & $59^{\circ} 48.13$ & 1372 & 3 & 11.08 \\
\hline
\end{tabular}


definition frame-grabs taken during the submersible and ROV dives.

After removal from the submersible or ROV bioboxes, Metallogorgia melanotrichos and associated brittle stars were briefly held in cold seawater until processed on board. Processing of the octocorals began by photographing each one with its associated brittle stars and making preliminary identifications if possible. Pieces of tissue were removed for molecular genetic analyses (by S. France, University of Louisiana, Lafayette), and then the specimens were fixed in a $5 \%$ formalin/-seawater bath for approximately 8 to $12 \mathrm{~h}$. Most brittle stars were extricated from the coral colonies before fixation, although some especially small individuals were left on the host throughout the preservation process. All specimens were transferred to $70 \%$ ethanol for long-term storage.

From the 66 Metallogorgia melanotrichos colonies collected from the New England and Corner Rise seamounts, 45 of the associated ophiuroids were brought to the Darling Marine Center for further examination (Table 1). Remaining specimens were placed in collections at the Smithsonian National Museum of Natural History (Washington, DC), the Yale-Peabody Museum (Newhaven, CT), and the Woods Hole Oceanographic Institution (MA). Ophiuroid disk diameter was recorded as the distance across the aboral surface from the point between the radial shields above one arm to the opposing interradius. Numbers of arms per individual with macroscopically visible signs of regeneration were recorded. The brittle star arms were tightly coiled around the branches of $M$. melanotrichos. Data from arms that were broken and/or missing after extraction from the host and arms removed for molecular studies by our colleagues were not included in the present study.

A gonadal portion from an arm of each brittle star was removed for histological examination to determine sex. The portions were paraffin embedded, transverse sectioned (12 to $14 \mu \mathrm{m})$, stained with Gomori's trichrome, and mounted on slides for examination via compound microscope. The presence of either testes or ovaries was used to determine the sex of each individual.

A wide size range of Metallogorgia melanotrichos colonies were collected. For ease of reference the colonies were grouped into 3 growth stages: youngest juvenile, Stage 1; intermediate, Stage 2; and fullgrown adult, Stage 3 . These stages are more fully characterized in the 'Results'.

The video and frame grabs were used to determine with certainty the number of brittle stars on each of the 66 Metallogorgia melanotrichos colonies collected, presence/absence of non-ophiuroid fauna associated with the octocoral, location of the brittle stars on the octocoral, and behavior of the brittle stars. In addition, the number and species of brittle stars associated with uncollected $M$. melanotrichos were recorded, and the presence/absence of Ophiocreas oedipus on other corals and/or the seabed was noted. Observations were made before and during collection while great care was taken to discern abnormal behavior caused by the submersible or ROV.

\section{RESULTS}

\section{Growth stages of Metallogorgia melanotrichos}

The Metallogorgia melanotrichos hosts of the 45 brittle stars collected for use in the present study were categorized into growth stages as follows (Table 1): Stage 1 juveniles (4 specimens), Stage 2 intermediates (6), and Stage 3 adults (35). Juvenile M. melanotrichos do not resemble the adults. Stage 1 juveniles consist of a single stalk bearing polyps along the central axis and a single terminal (axial) polyp at the apex. The juvenile gradually develops branches along the central axis that may be branched once or twice and bear additional polyps (Fig. 2a,b). As the colony matures, polyps are no longer seen on the central axis itself, and a cluster of dichotomously terminal branches replaces the axial polyp or one of the branches bears the axial polyp (Stage 2). This cluster forms a burgeoning 'parasol' of dichotomous branches while the axial branches are retained along the stalk (Fig. 2c). Finally, the axial branches disappear and the adult form (Stage 3) is fully manifested as a solitary stalk with a full crown of polyp-covered dichotomous branches (Fig. 2d,e). As the colony ages further, branches in the crown continue to subdivide until the crown is densely branched. The Stage 1 and 2 host colonies were seen to have the same MSH1 gene sequence as the adult (Stage 3) specimens identified as Metallogorgia melanotrichos using morphological methods (S. France pers. comm.).

\section{Association between Metallogorgia melanotrichos and Ophiocreas oedipus}

Each collected Metallogorgia melanotrichos hosted only 1 individual Ophiocreas oedipus. In addition, there were $94 \mathrm{M}$. melanotrichos definitively seen to be hosting a single brittle star resembling $O$. oedipus in the video frame grabs. The dive tracks did not coincide on repetitive visits to seamounts, therefore multiple observations of the same host individual did not occur. O. oedipus was found on no other coral in our explorations nor was it observed on the seabed via submersible/ROV video and frame grabs. No other ophiuroid species was found on living $M$. melanotrichos 

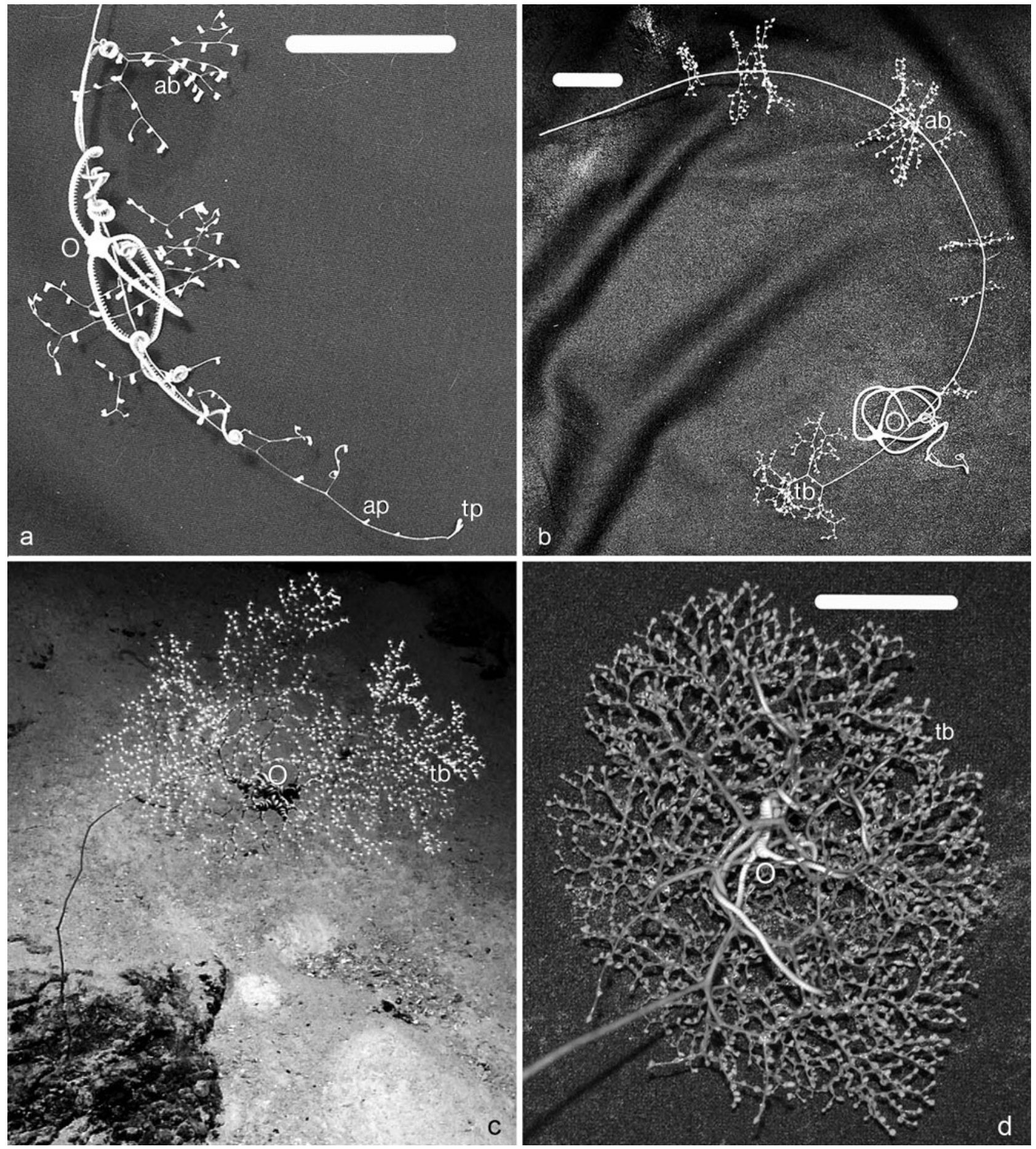

Fig. 2. Metallogorgia melanotrichos and Ophiocreas oedipus. Growth stages of M. melanotrichos. A single O. oedipus (O) is associated with each $M$. melanotrichos colony. (a) Stage 1, defined by a single terminal polyp (tp) and axial polyps (ap) arising from a central axial stalk. Axial branches (ab) are present in more mature Stage 1 colonies. (b) Stage 2, terminal branches (tb) have replaced the terminal polyp. The axial branches still arise from the stalk but the axial polyps are no longer present. (c) In situ image of Stage 3 M. melanotrichos with full crown of terminal branches obscuring the associated O. oedipus. (d) Stage 3, axial polyps and branches are no longer present in the adult colony. Scale bars $=5 \mathrm{~cm}$ 
across the New England and Corner Rise seamounts. However, other brittle star species were observed around the base of $M$. melanotrichos colonies, sometimes hanging from the detritus-covered base of the stalk. No other macroscopic species were observed on this coral, with the exception of 1 individual on Bear seamount that appeared to be dead. One O. oedipus was present despite the poor health of the octocoral.

Very small Ophiocreas oedipus were observed on the central stalk of Stage 1 Metallogorgia melanotrichos (Fig. 2a,b). As the octocorals age, brittle stars begin to move higher up the stalk, and in 4 of the 6 Stage 2 hosts, brittle stars had moved into the developing crown. Once the crown was fully developed and the axial branches lost, brittle stars were always found among the branches of the crown.

The disk diameters of Ophiocreas oedipus residing in the 3 growth stages of octocoral hosts differed significantly according to the host growth stage (KruskalWallis 1-way ANOVA, $H=22.24, \mathrm{p}<0.001, \mathrm{n}=45$ ) (Fig. 3). The disk diameter of brittle stars perched on Stage 1 Metallogorgia melanotrichos was $6.66 \mathrm{~mm}$. The mean diameter of those residing on Stage 2 hosts was $9.06 \mathrm{~mm}$ and those on Stage 3 octocorals had mean diameters of $12.13 \mathrm{~mm}$ (Table 1). Sex of $O$. oedipus was determined from histological preparations since this species does not exhibit external sexual dimorphism in disk diameter (Mann-Whitney $U$-test, $U=270, \mathrm{p}=0.95, \mathrm{n}=43$ ). Females had a mean disk diameter of $12.86 \mathrm{~mm}$ and males $11.04 \mathrm{~mm}$.

Ophiocreas oedipus was always observed with its arms coiled around the central axis of the coral when

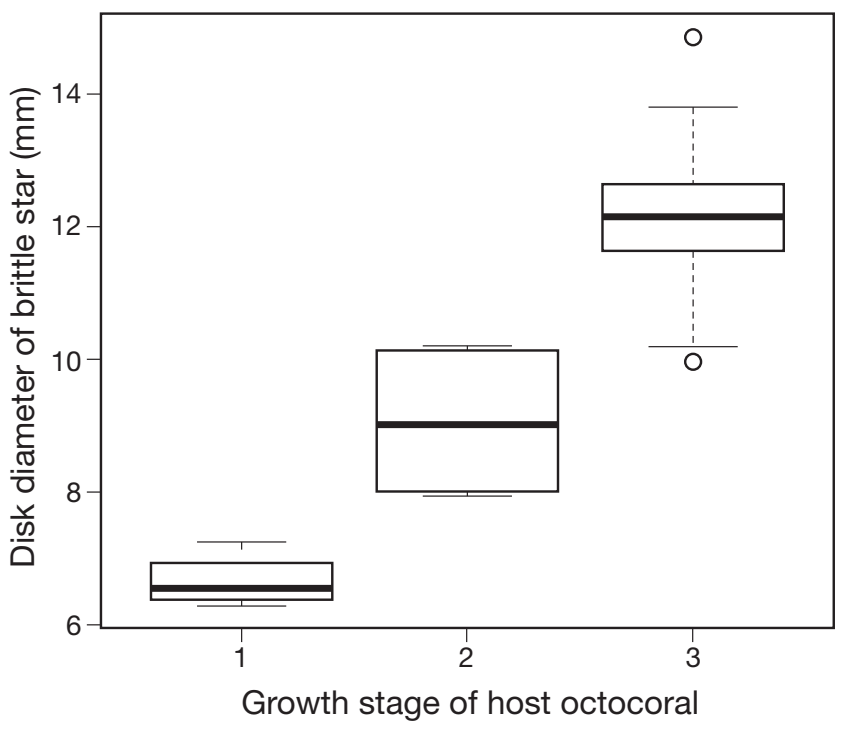

Fig. 3. Ophiocreas oedipus and Metallogorgia melanotrichos. Disk diameters of $O$. oedipus residing on the 3 growth stages (see Table 1) of M. melanotrichos hosts. (O): outliers; t-bars: range; solid bars: medians; boxes: 25 th to 75 th percentiles young and around the branches in the center of the crown of the coral host when mature (Fig. 2d). Often the distal portion of all 5 arms was extended into the surrounding water. $O$. oedipus did not appear to avoid contact with the stinging polyps of Metallogorgia melanotrichos, as the ophiuroid waved its arms about. Brittle stars stopped any activity or feeding postures when physically disturbed by the submersible or ROV manipulator.

\section{Regeneration of Ophiocreas oedipus}

Although there were 45 Ophiocreas oedipus available for the analysis of regeneration, only $82.7 \%$ of their arms were available and intact enough to make a confident assessment of regeneration. Of those, 15.1\% showed macroscopic signs of regeneration. Only one specimen had 3 arms regenerating, the rest had 2, 1, or none. All but one of the regenerating individuals were on Stage 3 host colonies.

\section{DISCUSSION}

While many seamount coral associates appear to be generalists, using several species of corals to gain height in the benthic boundary layer (Buhl-Mortensen \& Mortensen 2004), the commensal relationship of Ophiocreas oedipus on Metallogorgia melanotrichos is species-specific and appears to be obligatory on the part of the brittle star. We do not think the relationship is mutualistic, since no benefit to the coral has been seen and is difficult to infer. Unlike the case of Astrobrachion constrictum (Farquhar) in New Zealand fiords, which cleans resuspended organic material from the surface of its antipatharian host (Grange 1991), no such activity has been seen or seems to be necessary in this comparatively particulate-poor deepsea environment.

The gross morphological differences between the younger stages and the adult Stage 3 caused us initially to consider the possibility that we might have found a new species of chrysogorgiid. However, it is now clear that the occurrence of polyps along the stalk and the presence of side branches mark the progression from a juvenile colony to an adult. The strong correlation between brittle star size and growth stage of the host suggests that Ophiocreas oedipus matures on, and with, its host, Metallogorgia melanotrichos. Obligate associations between brittle stars and gorgonians are not well documented. Emson \& Woodley (1987) found Asteroschema tenue restricted to Ellisela barbadensis, but they did not see juveniles. The phenomenon of a single commensal individual settling 
on and maturing with its host has not been previously observed.

The high fidelity between Ophiocreas oedipus and Metallogorgia melanotrichos has many implications. O. oedipus appears to be dependent on M. melanotrichos for survival on the New England and Corner Rise seamounts. While anthropogenic impacts such as deep-sea trawling continue to put deep coral communities at risk (Clark \& Koslow 2007, Waller et al. 2007), the organisms that live on the corals are equally at risk if they are not able to thrive in other habitats such as on the seabed. The presence of species-specific associations may be an indicator of higher biodiversity on seamounts (McClain 2007); however, biodiversity may be only slightly elevated as obligate associations are rare (Buhl-Mortensen \& Mortensen 2004).

Such a tight association would seem limiting and is likely to have persisted for thousands of years at these depths in such a stable environment relative to that of shallow coral communities. Commensal associations between euryalids and other invertebrates can be found in the fossil record as early as the late Carboniferous. Fossils of the Onychasteridae, ancestors of the Asteroschematidae dating to 300 to 325 million yr ago, were observed coiled around the anal cone of stalked crinoids (Clark 1908, Wachsmuth \& Springer 1897).

The mechanism that allows Ophiocreas oedipus to recognize its host is unknown. Brittle star larvae may use chemical cues to detect their hosts and either settle directly onto a young coral or onto the seabed. Recently settled $O$. oedipus would not have been visible on the seabed at the resolution of our video. However, the cost of settling on the seabed and then searching for a particular host species would be very high, since the host corals are widely dispersed across the seamounts, often occurring many tens of meters from another colony. The host colonies do occur in clusters in some locations, but most are solitary. It is more likely that the larvae settle onto the juvenile coral from the water column, as inferred for Astrobrachion constrictum (Grange 1991, Stewart \& Mladenov 1997).

No other ophiuroids are found on Metallogorgia melanotrichos, despite the presence of many other ophiuroid species on the surrounding benthos and nearby corals. Also, only one Ophiocreas oedipus resides on a single octocoral. When the coral is young, it is possible that its defensive polyps and chemicals are not as toxic to the settling brittle star and the brittle star develops a resistance to the coral as it grows. Other possible associates, e.g. brittle stars or other commensals, may not be able to withstand the defense mechanisms of $M$. melanotrichos, thus explaining the lack of other associations. This hypothesis could be tested through in situ manipulations. Pelagic larvae of $O$. oedipus may recognize the presence/absence of
O. oedipus on a young coral. Alternatively, territorial aggression could maintain $O$. oedipus' solitary lifestyle, but this is unsupported by any video observations. The lack of regenerating arms on young brittle stars may be evidence that physical aggression is not taking place; rather a chemical signal may indicate that a host is already occupied. Another possibility is that the resident brittle star may remove potential competitors when they are in a younger, post-larval stage. Finally, the phenomenon of growing up together may simply be because host octocorals are likely rarer than newly settling $O$. oedipus. If the brittle stars live as long as the hosts and fatalities from predation are low, few adult $M$. melanotrichos would ever be vacated. On the Corner Rise and New England seamounts, juvenile M. melanotrichos possibly represent the only members of the species available without current brittle star residents.

The brittle stars on intermediate Stage 2 hosts were either in the burgeoning parasol of polyps or curled around the stalk. At some point in the development of the 2 species, Ophiocreas oedipus ascends into the crown to live. This may happen when the octocoral's crown becomes large enough to protect the brittle star and/or when the brittle star achieves a state of maturity that allows it to withstand the density of stinging polyps found in the complex of branches of the Metallogorgia melanotrichos crown. Our video observations lead us to believe the brittle stars are not adversely affected by coming into contact with host polyps.

The evolutionary advantage of maintaining a uniform, solitary population distribution over hosts is not obvious. Food availability may play a role, but nearby arborescent corals hosting many brittle stars would seem to dispel that conclusion. Since there appear to be many possible dwelling locations within the larger adult Metallogorgia melanotrichos, one colony could, in theory, host several brittle stars. When coral colonies are no more than an axial stalk with a few polyps, there are fewer places for the young brittle stars to perch and take advantage of the available currents. That no other larval Ophiocreas oedipus settles on the coral may be the result of an evolved survival mechanism. In addition, a single ophiuroid perched and protected within the center of a $M$. melanotrichos crown of polypcovered branches is less likely to be harmed by predators than multiple ophiuroids located nearer the outer limits of the coral's crown. If there is a predatory attack, damage is not likely to be fatal if arms are clipped off. Of the $15 \%$ incidence of regenerating arms among those arms analyzed, in most cases only one arm was damaged. As the brittle stars wave their arms into the prevailing current for food, an arm could be bitten off and the brittle star would have a chance to curl into the interior of its host's protective crown. Our 
in situ observations support the use of such a defense mechanism. The brittle stars were seen extending their arms out into the water and retracting them upon being disturbed.

Addendum (after manuscript submission): In March 2009 the ROV 'Global Explorer' was used from the RV 'F. G. Walton Smith' to collect additional specimens from the vicinity of the Bahamas platform. One very small specimen of Metallogorgia melanotrichos, $11 \mathrm{~cm}$ in length and bearing only 13 polyps, was collected at $1696 \mathrm{~m}$ depth. On its central axis was an Ophiocreas oedipus with disk diameter of $1.5 \mathrm{~mm}$. These are by far the smallest of all the specimens found and indicate that this relationship indeed is formed at a very early stage in the life of both partners. On the other hand, several older $M$. melanotrichos colonies were also seen, one of which was clearly dead but still harbored a living adult $O$. oedipus.

Acknowledgements. This work was funded by the United States National Oceanic and Atmospheric Administration's Office of Ocean Exploration. We thank the officers and crews of the RV 'Atlantis' (cruises AT8-1, AT 12-1) and NOAA Ship 'Ronald H. Brown' (cruises RB04-04, RB05-03), the pilots, crews and technicians of the DSV 'Alvin' and ROV 'Hercules', and our shipboard colleagues, who became expert at spotting the juvenile octocorals. We greatly appreciate the collaborative efforts of S. C. France and his students, who provided genetic data to substantiate the identification of the juvenile octocoral Metallogorgia melanotrichos. T. O'Hara, Museum Victoria, and I. Smirnov, Zoological Institute, St. Petersburg, confirmed the identity of the brittle star when visiting the Smithsonian Institution in Washington, DC.

\section{LITERATURE CITED}

Buhl-Mortensen L, Mortensen PB (2004) Symbiosis in deepwater corals. Symbiosis 37:33-61

Clark AH (1908) Descriptions of new species of crinoids, chiefly from the collections made by the US Fisheries Steamer 'Albatross' at the Hawaiian Islands in 1902, with remarks on the classification of the Comatulida. Proc US Natl Mus 34:209-239

Clark HL (1911) North Pacific ophiurans in the collection of the United States National Museum. US Natl Mus Bull 75: $1-302$

Submitted: February 24, 2009; Accepted: May 17, 2009
Clark MR, Koslow JA (2007) Impact of fisheries on seamounts. In: Pitcher TJ, Morato T, Hart PJB, Clark MR, Haggan N, Santos RS (eds) Seamounts: ecology, fisheries and conservation. Blackwell, Oxford

Eckelbarger KE, Watling L, Fournier H (2005) Reproductive biology of the deep-sea polychaete Gorgoniapolynoe caeciliae (Polynoidae), a commensal species associated with octocorals. J Mar Biol Assoc UK 85:1425-1433

Emson RH, Woodley JD (1987) Submersible and laboratory observations on Asteroschema tenue, a long-armed euryaline brittle star epizoic on gorgonians. Mar Biol 96:31-45

Fujita T (2001) Submersible observations on the euryaline brittle star, Asteronyx loveni (Echinodermata, Ophiuroidea), living in association with a gorgonian. In: Barker M (ed) Echinoderms 2000: Proc 10th Int Conf, 31 Jan-4 Feb 2000, Dunedin. A. A. Balkema, Amsterdam, p 267-272

Fujita T, Ohta S (1988) Photographic observations of the life style of a deep-sea ophiuroid Asteronyx loveni (Echinodermata). Deep-Sea Res A 35:2029-2043

Grange KR (1991) Mutualism between the antipatharian Antipathes fiordensis and the ophiuroid Astrobrachion constrictum in New Zealand fjords. Hydrobiologia 216-217: 297-303

Hendler G, Miller JE (1984) Feeding behavior of Asteroporpa annulata, a gorgonocephalid brittlestar with unbranched arms. Bull Mar Sci 34:449-460

Lyman T (1882) Ophiuroidea. Report of the scientific results of the voyage of the H.M.S. 'Challenger' 1873-1876. Zoology 5:1-386

> McClain CR (2007) Seamounts: Identity crisis or split personality? J Biogeogr 34:2001-2008

McKnight DG (2000) The marine fauna of New Zealand: basket-stars and snake-stars (Echinodermata: Ophiuroidea: Euryalinida). NIWA Biodiversity Mem 115, Wellington

Stewart BG (1998) Can a snake star earn its keep? Feeding and cleaning behaviour in Astrobrachion constrictum (Farquhar) (Echinodermata: Ophiuroidea), a euryalid brittle-star living in association with the black coral Antipathes fiordensis (Grange 1990). J Exp Mar Biol Ecol 221:173-189

> Stewart BG, Mladenov PV (1997) Population structure, growth and recruitment of the euryalinid brittle-star Astrobrachion constrictum (Echinodermata: Ophiuroidea) in Doubtful Sound, Fiordland, New Zealand. Mar Biol 127: 687-697

Wachsmuth C, Springer F (1897) The North American Crinoidea camerata. Mem Mus Comp Zool Harv Coll 2021:361-837

Waller R, Watling L, Auster P, Shank T (2007) Anthropogenic impacts on the Corner Rise seamounts, north-west Atlantic Ocean. J Mar Biol Assoc UK 87:1075-1076

Proofs received from author(s): October 1, 2009 